\title{
Rituximab and Hyaluronidase Human
}

National Cancer Institute

\section{Source}

National Cancer Institute. Rituximab and Hyaluronidase Human. NCI Thesaurus. Code C136821.

A combination preparation of rituximab, a genetically eng ineered chimeric murine/human immunog lobulin (Ig) G1 kappa monoclonal antibody directed against the CD20 antigen, and the recombinant form of the human enzyme hyaluronidase, with antineoplastic activity. Upon subcutaneous administration of rituximab and hyaluronidase human, the hyaluronidase reversibly depolymerizes the polysaccharide hyaluronan in the subcutaneous tissue. This increases the permeability of the subcutaneous tissue and enhances the absorption of rituximab into the systemic circulation. In turn, rituximab targets and binds to CD20 expressed on tumor cells, and induces tumor cell lysis primarily through the induction of complement dependent cytotoxicity (CDC) and antibodydependent cell mediated cytotoxicity (ADCC). When administered subcutaneously, hyaluronidase, an endog lycosidase, increases the dispersion and absorption of coadministered drugs. CD20 is expressed on the surface of pre-B and mature Blymphocytes, and is overexpressed in a variety of B-cell malignancies. 